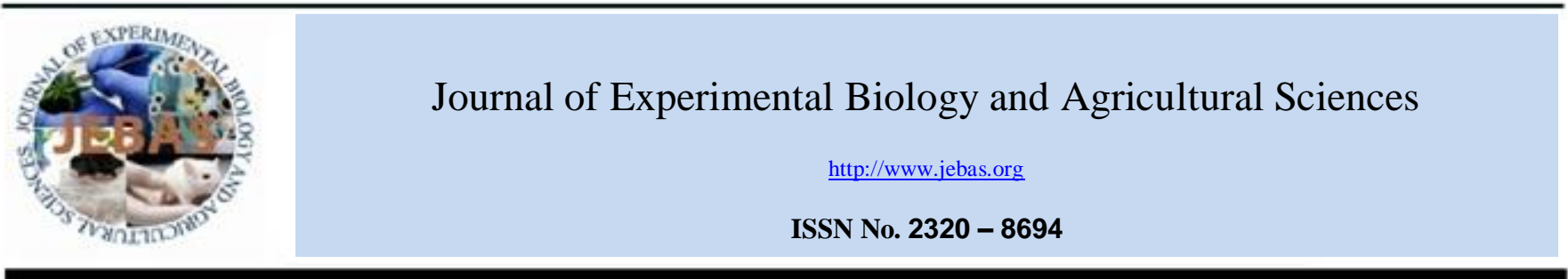

\title{
PROFILING OF NUTRITIONAL TRAITS IN INDIGENOUS WHEAT CULTIVARS
}

\author{
Noushad Parvez ${ }^{1}$, Hardev Choudhary ${ }^{1 *}$, Swati Parihar ${ }^{1}$, Kelvin Gandhi $^{2}$, Satveer Singh ${ }^{1}$, \\ Rajkumar Rathore ${ }^{1}$, Rudrappa Zulapi ${ }^{1}$, Bajranglal Kasva ${ }^{1}$, Ranjit Kumar ${ }^{1}$, \\ Prakash S. Raghuvanshi ${ }^{1}$, Agyaram Verma ${ }^{1}$
}

${ }^{1}$ National Innovation Foundation-India, Autonomous Body of Department of Science \& Technology, Govt. of India, Grambharti, Amrapur, Gandhinagar-Mahudi

Road, Gandhinagar, Gujarat, Pin: 382650, India

${ }^{2}$ Navsari Agricultural University, Navsari, Gujarat, 396450, India

Received - November 23, 2018; Revision - January 08, 2019; Accepted - January 21, 2019

Available Online - February 5, 2019

DOI: http://dx.doi.org/10.18006/2019.7(1).1.11

\section{KEYWORDS \\ Farmer's crop variety \\ Nutrients \\ Traditional cultivar \\ Wheat \\ Gujarat}

* Corresponding author

E-mail: hardev@ nifindia.org (Hardev Choudhary)

Peer review under responsibility of Journal of Experimental Biology and Agricultural Sciences.

Production and Hosting by Horizon Publisher India [HPI] (http://www.horizonpublisherindia.in/).

All rights reserved.

\begin{abstract}
Farmers' traditional crop varieties are the valuable source of diversity, nutritional heritage and genetically important traits. Wheat is an important cereal crop serving as a major source for energy and nutrients for millions throughout the world. Modern trend of promoting and cultivating high yielding variety has suppressed the existence of indigenous varieties and resulting in the loss of the same. Many traditional wheat cultivars have disappeared after the green revolution. By looking at the rich nutrient properties and needs of farmers' crops varieties, many efforts are being under taken for their protection and promotion. Present study was performed to measure the nutrient levels in whole grain flour of thirteen different farmers' wheat cultivars in comparison with check-released varieties. The average composition showed a significant variation among farmers' and check wheat varieties; among various tested varieties, wheat cv. Mohit-gold reported with higher potassium (K) and magnesium $(\mathrm{Mg})$ contents. While, Kudrat-7 contained higher fibre content whereas $R k-7$ exhibited significantly higher content of carbohydrate and sugar. Overwhelming higher iron content was reported in Bansi-local, $H Z G-30$ and Kudrat-7 cultivars.
\end{abstract}

All the article published by Journal of Experimental Biology and Agricultural Sciences is licensed under a Creative Commons Attribution-NonCommercial 4.0 International License Based on a work at www.jebas.org.

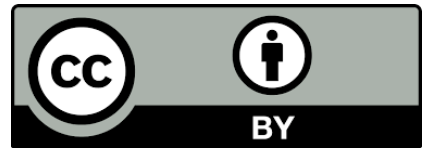




\section{Introduction}

India is a country of diversity where various crops and thousands of cultivars have been conserved and grown since ancient times. It has been reported that in India production of wheat, barley and jujube crop was started before about 9000 B.C. (Stein, 1998). Since then, there has been a revolutionary change in crop cultivation. Wheat is consumed as staple food source in almost every state of India where traditional and modern methods are used for the cultivation and consumption of wheat. Wheat flour and its value added products are primarily used as an energy food, but it is also known for its broad nutrient properties.

It is factual that if traditional cultivars are grown in an organic way, their nutrients can be used appropriately. During 1967-68 and 2003-04 when production of cereal crops increased two times, production of wheat crop was raised up by three times (Nagarajan, 2005). Due to this reason, green revolution in India is also known as 'wheat revolution'. Wheat is the main crop, which remained benefited after the green revolution in India. It is ranked fourth among the top fifty agriculture commodities of the world and as per the report of United States Department of Agriculture, during 2015-16, India followed China in the leading wheat producing countries and shared 11.78 percent and 0.40 percent of worldwide wheat production and global wheat exports respectively (Anonymous, 2018).

In India, every year around sixty popular wheat varieties are cultivated, in which the top ten varieties account for sixty per cent of the national demand of wheat (Nagarajan \& Singh, 1997). Newly introduced and released varieties are trait specific and genetically uniform. These varieties are drastically used by most of the farmers for higher yield but these are also responsible for the loss of diversity of indigenous varieties and cultivars of wheat. India has rich experience and huge area with outstanding diversity for wheat cultivation (Nagarajan, 2005; Fernandes, 2017). Farmers' cultivars are genetically diverse but after the green revolution, traditional varieties are rapidly disappearing resulting in loss of genetic diversity due to non-preference over hybrid varieties. For sustainable agriculture, affordable food production and food security, conservation of agrobiodiversity has been marked to play a vital role.

Major concern is associated with modern wheat crop varieties and its cultivation methods, which mainly focuses on higher yield, without concerning about the essential nutritional values and agrochemical toxicity issues (Reynolds et al., 1999; Garvin et al., 2006). Modern monoculture farming indirectly violates the balanced nutrition right of individual; it is also responsible for the increased incidences of micronutrient deficiencies (Yu \& Tian, 2018). Such changes in major nutrition source coupled with sluggish lifestyle resulted enhance instances of cardiovascular disease, type two diabetes and cancer in many developing countries (Key et al., 2002; Musaiger \& Al-Hazzaa, 2012). Due to this, various national and international initiatives are under way focusing diversity and nutrient density traits for variety improvement programs.

In present scenario, many farmers conserve \& cultivate traditional varieties and improve the varieties through mass selection from the cultivars popular in the area. The cultivars either traditionally grown/ improved by the farmers or having a wild relative/land race or about which the farmers possess the common knowledge are known as Farmers' plant varieties (Lushington, 2012). According to the recent figures of registered varieties in India under Protection of Plant Varieties and Farmers' Rights (PPV \& FR) Authority (2018), 42.45 percent of the crop varieties registered (under PPV \& FR Act, 2001) were farmers' varieties, where maximum 96.78 percent farmers' varieties belongs to paddy only (till February 2018). For preserving crop genetic diversity and promoting the cultivation of traditional and farmers' developed varieties, Government of India is working through public sectors organizations like Indian Council of Agricultural Research (ICAR) and its allied research institutes, Central and state Agricultural Universities, Non-governmental organizations as well as private sectors organizations. During 2015-17, the study was conducted by National Innovation Foundation, India, setup of Department of Science and technology, Government of India working as a national initiative to strengthen the grassroots technological innovations and outstanding traditional knowledge. The study mainly focussed on comparison of composition of thirteen farmers' wheat varieties with two checks. The study intends to provide scientific evidence to the claims of the innovators and may act as a basis for inclusion of these nutrient rich cultivars in the national nutrition supplement programs.

\section{Materials \& Methods:}

\subsection{Experimental design}

For obtaining the wheat flour samples for the analysis a randomized block design containing fifteen wheat cultivars (13 farmers' and 2 checks) with three replications was sown in Gandhinagar $\left(23.376064^{\circ} \mathrm{N}, 72.719488^{\circ} \mathrm{E}\right)$, Gujarat, during 2015-2017. This study included fifteen potentially cultivated wheat varieties from different agro climatic wheat cultivation zone viz. twelve farmers' cultivars from the database of National Innovation Foundation - India, one from farmers' check durum variety Bansi-local and two check varieties ( $G W-496$ and $H D$-2967) most widely cultivated in Gujarat and North East \& North West Zone respectively (Table 1). 


\begin{tabular}{|c|c|c|}
\hline 3 & & Parvez et al \\
\hline Denomination (Wheat cv.) & Farmer & Agro-climatic zone of wheat, India \\
\hline Mohit-gold ${ }^{\#}$ & Shri Satveer Singh, Uttar Pradesh & North-Western Plains Zone (NWPZ) \\
\hline Rajyog \# & Shri Rajkumar Rathore, Madhya Pradesh & Central Zone (CZ) \\
\hline$H Z G-30^{\#}$ & Shri Rudrappa Zulapi, Karnataka & Peninsular Zone (PZ) \\
\hline$B L K$-balaji ${ }^{\#}$ & Shri Bajranglal Kasva, Rajasthan & North-Western Plains Zone (NWPZ) \\
\hline Bansi-local $^{* *}$ & $\begin{array}{l}\text { Farmer's check variety (Shri Surendra Kumar, Uttar } \\
\text { Pradesh) }\end{array}$ & North-Western Plains Zone (NWPZ) \\
\hline$R k-2, R k-4, R k-7, R k-$ Shital ${ }^{\#}$ & Shri Ranjit Kumar, Uttar Pradesh & North-Eastern Plains Zone (NEPZ) \\
\hline Kudrat-7, Kudrat-9, Kudrat-17 ${ }^{\#}$ & $\begin{array}{l}\text { Shri Prakash S. Raghuvanshi, } \\
\text { Uttar Pradesh }\end{array}$ & North-Eastern Plains Zone (NEPZ) \\
\hline$A R-64^{\#}$ & Shri Agyaram Verma, Bihar & North-Eastern Plains Zone (NEPZ) \\
\hline$G W-496$ & State check variety & North-Western Plains Zone (NWPZ) \\
\hline$H D-2967$ & National check variety & North East and North West Zone \\
\hline
\end{tabular}

\#Information on wheat varieties taken from the database of National Innovation Foundation - India (http://www.nifindia.org). ** Variety was used as farmers' check

\subsection{Estimation of nutrient and mineral content in farmers'} wheat varieties

\subsubsection{Preparation of sample}

The primary step before milling is cleaning of grains, which was carried out manually to eliminate foreign seeds, soil particles and broken kernels. Each sample of wheat varieties were allowed to dry for 48 hours and subsequently underwent milling at laboratory by using Multipurpose Pulveriser Machine (Sieve size -1), Savalia Electricals, Ahmedabad, Gujarat, India. The flour samples of each variety were sealed in air-tight containers and placed at $18{ }^{\circ} \mathrm{C}$ in a deep freezer for storage. The flour samples were thawed at room temperature prior further analysis. For this study, the wheat flour were analysed for the content of carbohydrate, protein, crude fibre, total soluble sugar, moisture, total fat, wet gluten, dry gluten and essential minerals such as iron $(\mathrm{Fe})$, calcium $(\mathrm{Ca})$, magnesium $(\mathrm{Mg})$ and potassium $(\mathrm{K})$.

\subsubsection{Estimation of major nutrient components}

Total carbohydrate content in the samples was assayed by the Anthrone method by taking glucose as the standard, whereas total soluble sugar was estimated by following the method of Dubois (Dubois et al., 1951; Yemn \& Wilus, 1954). Moisture and ash content of the flour was determined by standard AACC procedure (AACC International, 2000). Total protein content in the samples was determined by the modified Lowry method (Lowry et al., 1951; Hartree, 1972). Total fat and crude fibre content of the sample was extracted and estimated by Nielsen and standard AOAC methods (AOAC, 1990; Nielsen, 1994), whereas the wet gluten and dry gluten content were analysed by standard method of gluten estimation (ISO 2170-1980, 1980; Kaushik et al. 2015).

\subsubsection{Estimation of essential minerals}

The essential mineral contents in the fine wheat flour samples were determined by methods prescribed in AOAC (2000) Absorbance of standard solution as well as sample solution was taken by an atomic absorption spectrophotometer (ICP MS Elan 9000. Perkin Elmer., USA).

\subsection{Statistical analysis}

Data generated from the assay of the wheat samples was compared by the analysis of variance (ANOVA) (0.05 level), Duncan multiple range test (at $\mathrm{P}<0.05$ significance level) and Pearson correlation ( 0.05 levels) coefficients with the help of GraphPad Prism (version 5.01).

\section{Results}

Nutrient contents of thirteen farmers' and two checks wheat varieties were calculated on different basis to allow comparison with literature data. ANOVA showed that there were significant differences $(\mathrm{P}<0.05)$ in the composition of wheat accessions (Verma \& Shrivastav, 2017).

\subsection{Carbohydrate and protein content}

The carbohydrate content of all wheat cultivars was found significantly different, ranged from 59.20 to 75.00 per cent (Figure $1 \& 2$ ). All the varieties found with higher value of 


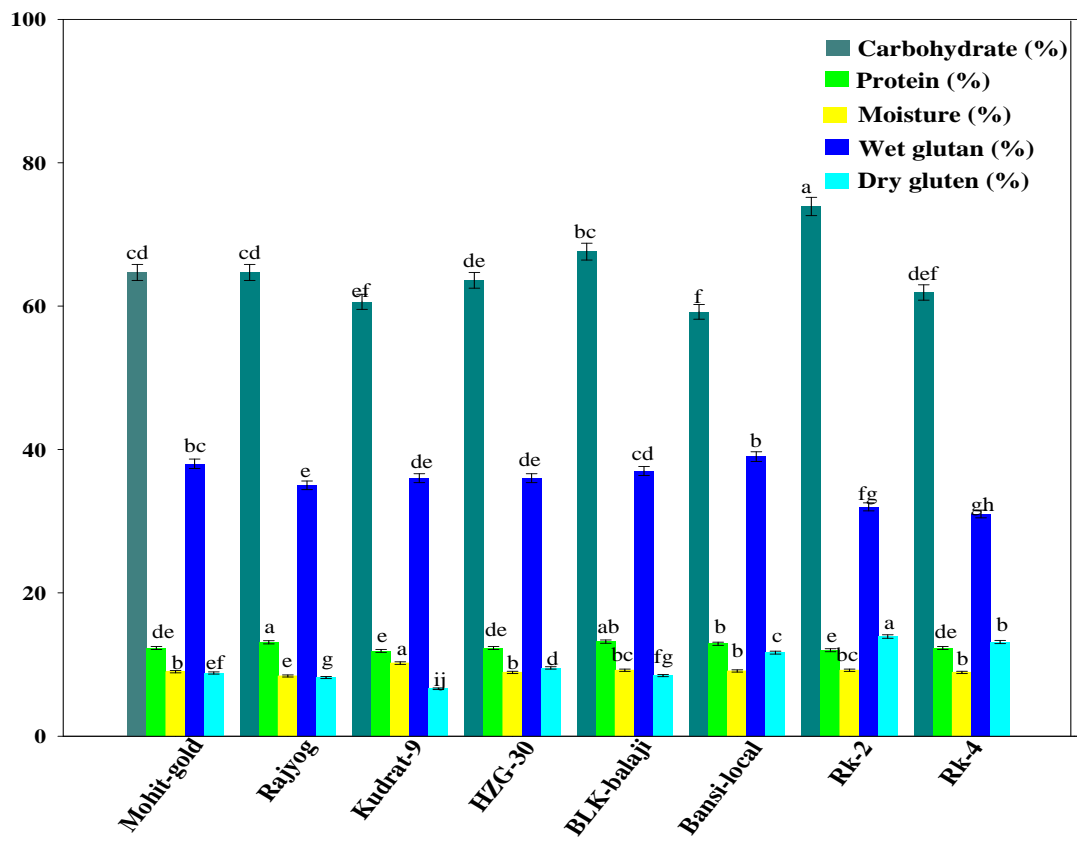

Figure 1 The carbohydrate, protein, moisture, wet gluten and dry gluten in eight wheat varieties. Data are means \pm standard error of three replicates $(n=3)$. Bars followed by different letters show significant difference according to Duncan multiple range test at $\mathrm{P}<0.05$ significance level.

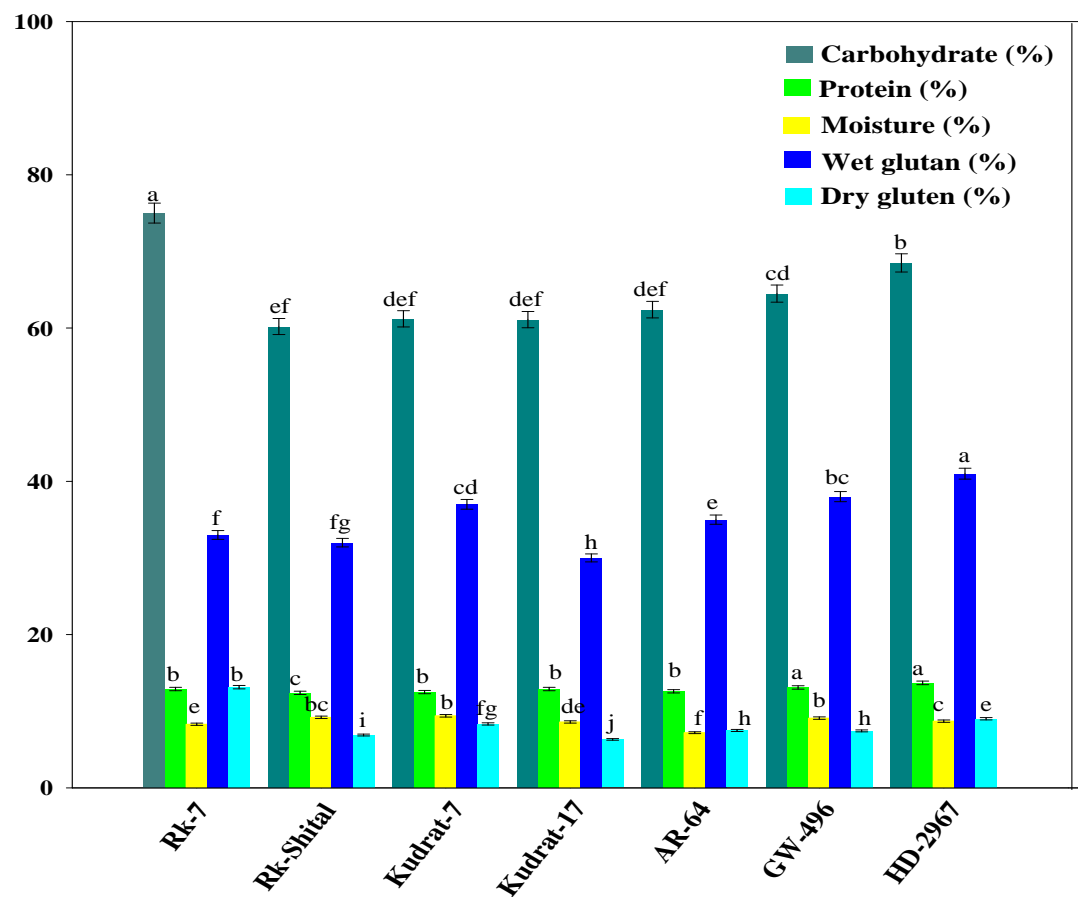

Figure 2 The carbohydrate, protein, moisture, wet gluten and dry gluten in seven wheat varieties. Data are means \pm standard error of three replicates $(n=3)$. Bars followed by different letters show significant difference according to Duncan multiple range test at $\mathrm{P}<0.05$ significance level carbohydrate except Bansi-local which showed 59.2 per cent of carbohydrate. Significantly higher carbohydrate content was found in $R k-2$ and $R k-7$ varieties with 73.9 and 75.0 percent respectively. Commercially cultivated varieties HD-2967 (68.5\%) showed highest carbohydrate composition as compared to $G W-496 \quad(64.5 \%)$ (Figure $1 \& 2$ ).

Among all varieties, maximum protein content was found in $H D$ 2967 variety, which was comparable to BLK-balaji (13.2\%) and Rajyog wheat $(13.1 \%)$. Check wheat variety $G W-496$ exhibited protein content as 13.1 per cent, which was found comparable with Rk-Shital (12.4\%), Kudrat-7 (12.5\%), AR-64 (12.6\%), Bansi-local (12.9\%), Rk-7 (12.9\%), Kudrat-17 (12.9\%) and Rajyog (13.1 $\%)$. Significant lower protein content was found in Kudrat-9 (11.9\%) and $R k-2 \quad(12.0 \%) \quad$ wheat varieties (Figure 1 \& 2); however, the values were higher as compared to average value of protein content.

\subsection{Moisture and gluten content}

The moisture percent of wheat varieties varied between $7.20-10.20$ per cent (Figure $1 \quad \& \quad 2$ ). The maximum moisture percent was exhibited in Kudrat-9 (10.2\%), whereas significantly lower moisture was in $A R-64$ wheat flour sample (7.2\%). Among the tested varieties, significantly higher wet gluten was exhibited by check variety $H D-2967$ (41\%) followed by Bansi-local (39 $\%)$ and $G W-496$ (38\%), however maximum dry gluten percent was found in $R k-2$ (13.91\%) followed by $R k-7$ (13.14 \%), Rk-4 (13.14\%) and Bansi-local (11.66\%). Significantly lower wet gluten was found in Kudrat-17 (30 \%) followed by $R k-4$ 
(31\%), whereas significantly lower dry glute percentage was found in $G W-496$ (6.32\%) followed by Kudrat-9 (6.62\%) and Rk-Shital (6.89\%) (Figure $1 \& 2$ ).

\subsection{Total ash and fat percent}

highest ash content $(2.07 \%)$, followed by Mohit-gold (2.03\%), whereas AR-64 Farmer's wheat variety $R k-7$ showed exhibited lowest ash percent $(1.45 \%)$ (Figure 3 \& 4). Among the check varieties, GW-496 showed higher ash content $(1.98 \%)$, whereas $H D-2967$ showed lower ash content $(1.83 \%)$. Fat values were found significantly different among wheat cultivars, farmer's variety AR-64 showed 3.00 per cent fat content whereas Bansi-local and Rajyog exhibited 2.8 per cent fat value, which was higher as compared to HD-2967 $(2.70 \%)$ and significantly higher as compared to fat content of $G W-496$ (2.6\%), whereas Kudrat-9 exhibited the lowest fat content (1.60\%) (Figure $3 \& 4)$.

\subsection{Total sugar and fibre content}

Total sugar content of farmers' wheat varieties and check varieties is mentioned in figure $3 \& 4$. Maximum sugar content was exhibited by $R k-7$ (4.8\%) and Rk-Shital varieties (4.2\%), whereas minimum total sugar content was found in Kudrat-17 (1.40\%) followed by $G W-496(1.5 \%)$. The fibre percent of all the wheat accessions were found above 1.0 per cent. Among the tested varieties, Kudrat-7 exhibited the significantly higher fibre percentage $(2.90 \%)$, followed by Kudrat-17 (2.70\%), HZG-30 (2.60\%) and Kudrat-9 (2.40\%), whereas Bansilocal contained the lowest fibre $(1.3 \%)$ followed by Rajyog wheat variety $(1.4 \%)$ (Figure $3 \& 4)$.

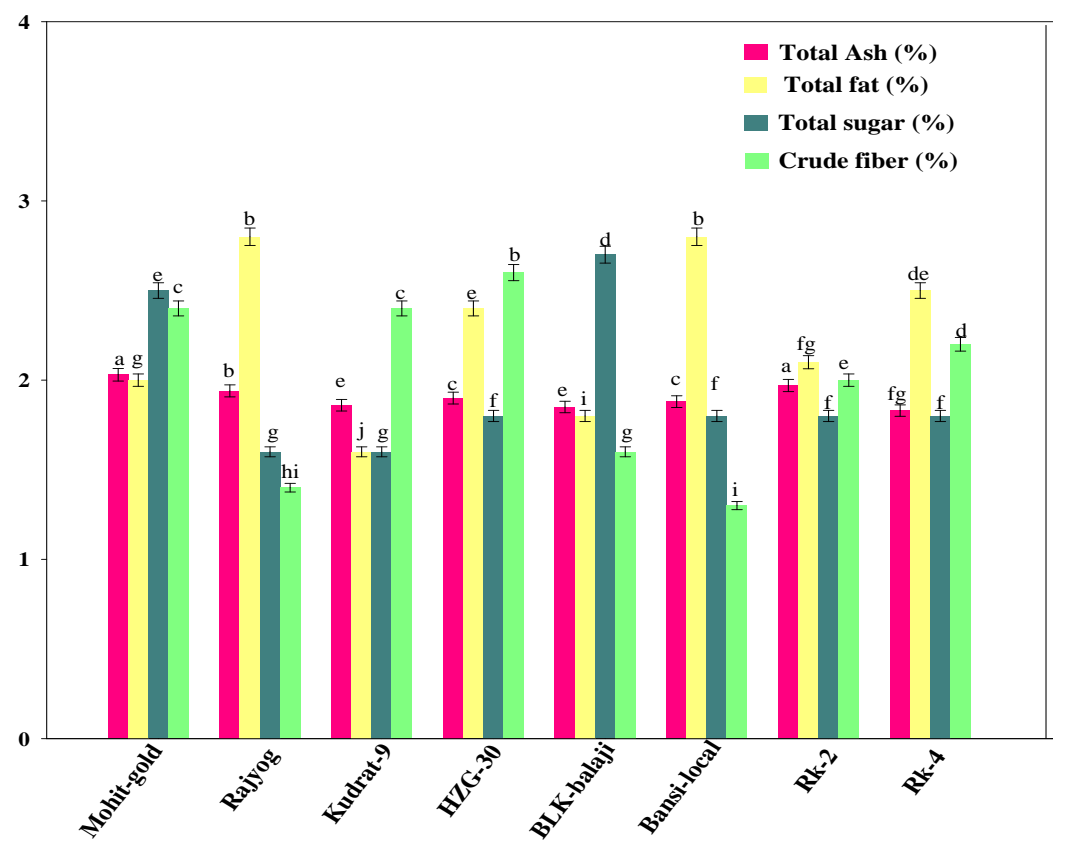

Figure 3 The total ash, fat, sugar and crude fiber in eight wheat varieties. Data are means \pm standard error of three replicates $(n=3)$. Bars followed by different letters show significant difference according to Duncan multiple range test at $\mathrm{P}<0.05$ significance level

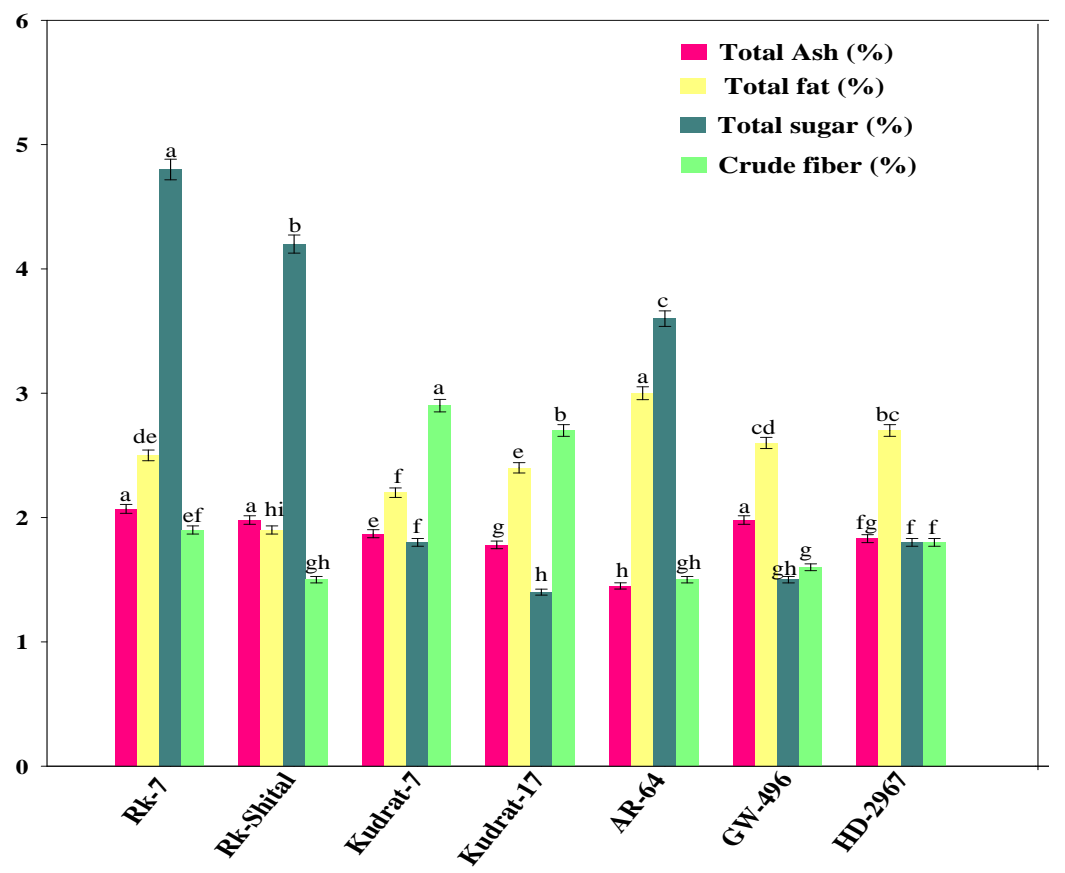

Figure 4 The total ash, fat, sugar and crude fiber in seven wheat varieties. Data are means \pm standard error of three replicates $(n=3)$. Bars followed by different letters show significant difference according to Duncan multiple range test at $\mathrm{P}<0.05$ significance level. 


\subsection{Essential minerals content}

Microelement iron (Fe) was found as the variant mineral component in farmers' and check varieties of wheat with a range of $35-175 \mathrm{mg} / \mathrm{kg}$. The abundance of iron was found in all the cultivars, which can be due to the soil and environmental conditions also, it is a subject of further investigation. Among all the varieties, remarkably high $\mathrm{Fe}$ was exhibited in Bansi-local $(175 \mathrm{mg} / \mathrm{kg})$ followed by HZG-30 (95 mg/kg), Kudrat-7 (85 $\mathrm{mg} / \mathrm{kg}$ ) and Kudrat-17 (70 mg/kg) (Figure 5). Range of calcium (Ca) and magnesium $(\mathrm{Mg}$ ) was found as $325-735 \mathrm{mg} / \mathrm{kg}$ (Figure 5) and $1105-1970 \mathrm{mg} / \mathrm{kg}$ (Figure 6) respectively. Significantly higher

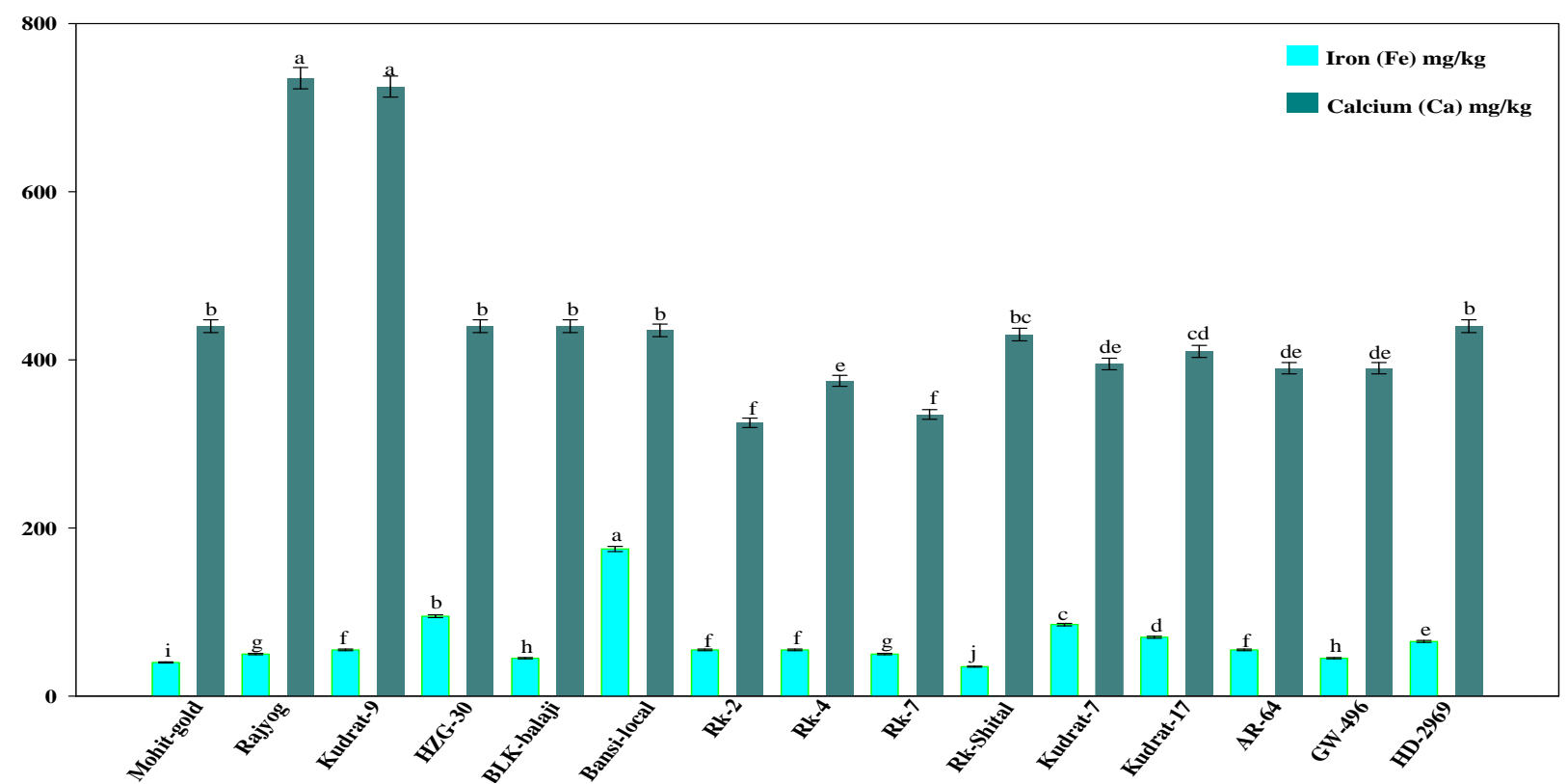

Figure 5 The iron $(\mathrm{Fe})$ and calcium $(\mathrm{Ca})$ content in farmers' wheat varieties. Data are means \pm standard error of three replicates $(\mathrm{n}=3$ ). Bars followed by different letters show significant difference according to Duncan multiple range test at $\mathrm{P}<0.05$ significance level.

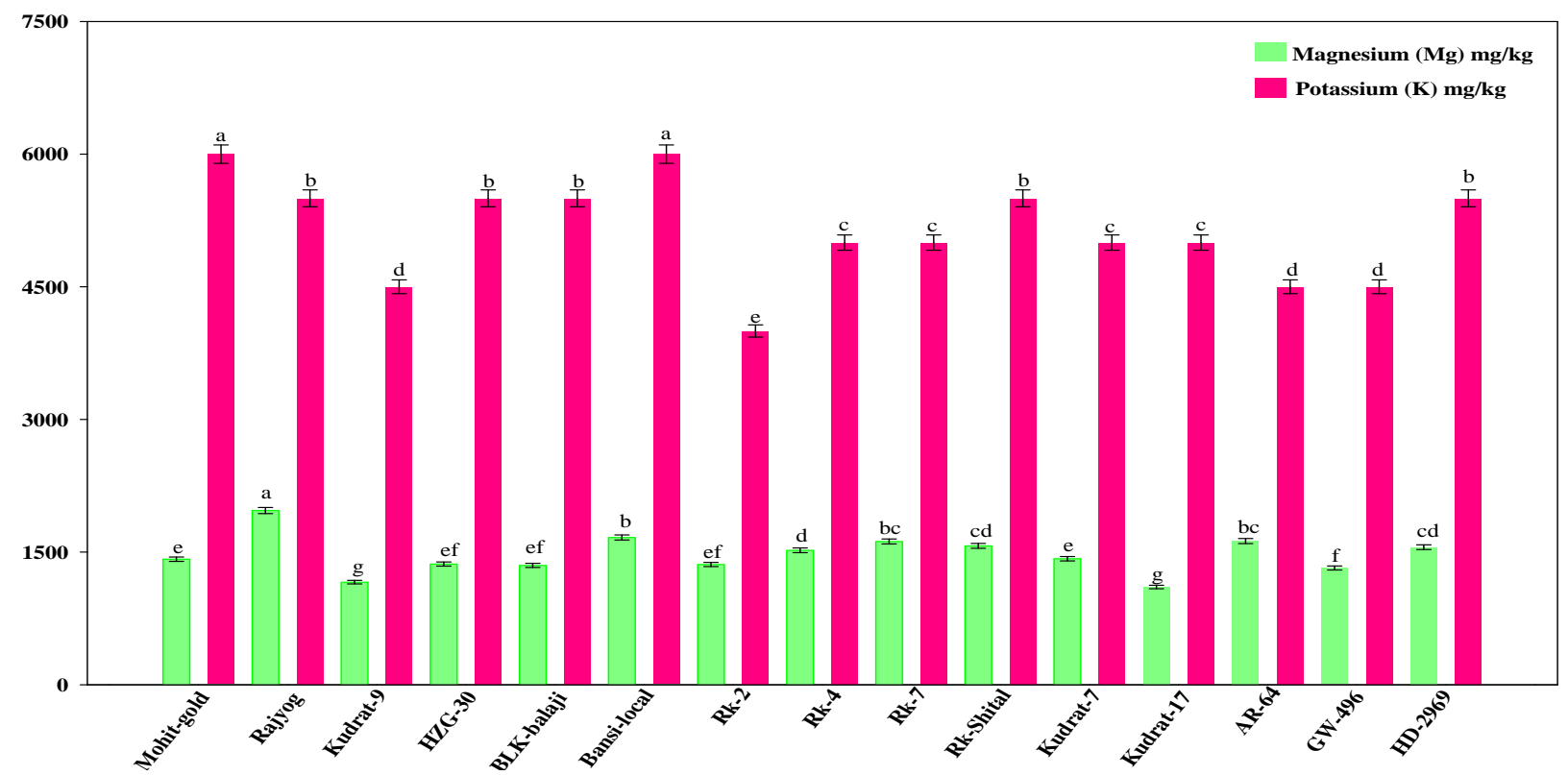

Figure 6 The magnesium $(\mathrm{Mg})$ and potassium $(\mathrm{K})$ content in farmers' wheat varieties. Data are means \pm standard error of three replicates (n=3). Bars followed by different letters show significant difference according to Duncan multiple range test at $\mathrm{P}<0.05$ significance level.

Journal of Experimental Biology and Agricultural Sciences http://www.jebas.org 
$\mathrm{Ca}$ and $\mathrm{Mg}$ content was found in Rajyog (735 and $1970 \mathrm{mg} / \mathrm{kg}$ respectively) followed by Kudrat-9 having $725 \mathrm{mg} / \mathrm{kg}$ as $\mathrm{Ca}$ content and Bansi-local with $1665 \mathrm{mg} / \mathrm{kg}$ as $\mathrm{Mg}$ content, however minimum Ca content was found in $R k-2(325 \mathrm{mg} / \mathrm{kg})$ followed by $R k-7(335 \mathrm{mg} / \mathrm{kg})$. Significantly, lower $\mathrm{Mg}$ content was found in Kudrat-17 (1105 mg/kg), Kudrat-9 (1160 mg/kg) and GW-496 $(1320 \mathrm{mg} / \mathrm{kg}$ ) (Figure 5, 6). Average $\mathrm{Ca}$ and $\mathrm{Mg}$ content were found as 447 and $1468.7 \mathrm{mg} / \mathrm{kg}$ respectively.

Average potassium (K) content in our study was found as 5133.3 $\mathrm{mg} / \mathrm{kg}$ and the range was $4000-6000 \mathrm{mg} / \mathrm{kg}$ (Figure 6). Maximum $\mathrm{K}$ content was found in Bansi-local and Mohit-gold $(6000 \mathrm{mg} / \mathrm{kg}$ ) followed by Rajyog, HZG-30, BLK-balaji, Rk-Shital and HD-2967 $(5500 \mathrm{mg} / \mathrm{kg}$ ) whereas minimum $\mathrm{K}$ content was recorded in $R k-2$ (4000 mg/kg) followed by Kudrat-9, AR-64 and GW-496 (4500 $\mathrm{mg} / \mathrm{kg}$ ).

The correlation among the nutrient components and mineral compositions in farmers' and check wheat cultivars (Table 2) exhibited that fat percent was in moderate positive correlation with $\mathrm{Mg}$ content $(\mathrm{r}=0.583, \mathrm{P}=0.023)$ and negative relationship with moisture percent $(\mathrm{r}=-0.759 * *, \mathrm{P}=0.001)$ at 0.01 level (Table 2).

\section{Discussion and Conclusion}

Present study revealed that farmers' wheat cultivars contain higher nutrient \& mineral contents and may be considered as promising genetic source for improving the nutrient values. Rajyog variety was found with higher protein, calcium, magnesium and possessed medium iron content. Bansi-local was found with higher Iron, magnesium, potassium, protein content and medium calcium content. Kudrat-17 was found with lower wet gluten content and medium to higher protein, fiber as well as iron content. HZG-30 was found with higher iron, Potassium, fiber content and medium calcium, wet gluten content. Mohit-gold was found with higher potassium content and medium to higher carbohydrate and fiber contents. BLK-balaji was found with higher potassium and protein content and medium to higher calcium and carbohydrate content. Check varieties $H D-2967$ and $G W-496$ contained highest protein content, which was comparable with $B L K$-balaji variety.

\subsection{Carbohydrates content}

The farmers' and released varieties were found comparable with the average carbohydrate values in wheat, which is 59.20 to 75.00 per cent (Souci et al., 2008; Belitz et al., 2009). Carbohydrates are an important energy source for human body. Wheat flour is having complex carbohydrates that also characterize the presence of calories level in it. Variation in carbohydrate compositions in wheat occurs mainly due to various factors like genotypes and cultivation conditions (Stone \& Morell, 2009). In earlier studies, it has reported that the carbohydrate range was 65 to $75 \%$ in American and Korean traditional wheat varieties (Stone \& Morell, 2009; Choi et al., 2016), whereas among 31 different Korean wheat cultivars, minimum carbohydrate content was found in Shinmichal-1 variety $(67.87 \%)$ and highest carbohydrate content was $74.6 \%$ in Jeokjoong variety (Choi et al., 2016). These results are in agreement with the findings of present study, which revealed that the farmers' wheat cultivars are diverse in carbohydrate content.

\subsection{Protein content}

The protein content in farmers' and check wheat varieties were found significantly higher i.e. more than 11.3 per cent (Triboi et al., 2003; Koehler \& Wieser, 2013). Protein may vary from 6 to more than 20 per cent in wheat cultivars depends on genotype and growing conditions (Triboi et al., 2003). Protein content is an important factor for quality; value added processing and economical value of wheat flour. Protein percent in wheat depends on variety and cultivation conditions (Triboi et al., 2003; Zhao et al., 2009). According to Cooper (2005) value of protein ranges from 10 to 15 per cent, in the context, this study corresponds to the previous study. Present study also revealed that in terms of protein content farmers' developed wheat varieties are rich which is alike to check released varieties under Gandhinagar condition.

\subsection{Moisture content}

The moisture percent of wheat varieties were found in the range of adequate level $(>11.5 \%)$ for longer storage and better avoidance of insect-pest spoilage (Ahmed et al., 2016). In a previous study comprised flour samples of seven traditional wheat varieties i.e. Inqulab-91, Bhakkar-2002, AS-2002, Shafaq-2006, Sehar-2006, Auqab-2000 and GA-2002 belongs of Punjab, Pakistan, it was found that minimum moisture was 9.64 per cent (Bhakkar-2002) and $9.79 \%(G A-2002)$ as maximum moisture content (Safdar et al., 2009). The moisture content is essential to maintain the final product quality. Present study revealed that the moisture level in wheat flour sample for both farmers' developed and check varieties was found in safe range which suggests its suitability for market and domestic usage.

\subsection{Gluten content}

During the study, the wet and dry gluten contents ranged from 30.00 to 41.00 per cent and 6.32 to 13.91 per cent, respectively. As gluten is responsible for the elasticity and extensibility characteristics of flour dough, testing of wet gluten provides the information regarding quantity and help in estimation of the quality of gluten in wheat or flour samples. Wet gluten also 
Table 2 Pearson correlation coefficients among nutrient composition values in farmers' and released check wheat varieties

\begin{tabular}{|c|c|c|c|c|c|c|c|c|c|c|c|c|}
\hline $\begin{array}{c}\text { Dry } \\
\text { gluten } \\
\%\end{array}$ & $\begin{array}{r}\text { Total } \\
\text { ash \% }\end{array}$ & $\begin{array}{c}\text { Wet } \\
\text { gluten \% }\end{array}$ & $\begin{array}{c}\text { Moisture } \\
\%\end{array}$ & $\begin{array}{c}\text { Total } \\
\text { fiber } \%\end{array}$ & $\begin{array}{c}\text { Total } \\
\text { sugar } \%\end{array}$ & $\begin{array}{c}\text { Fat } \\
\%\end{array}$ & $\begin{array}{c}\text { Protein } \\
\%\end{array}$ & $\begin{array}{l}\text { Carbohy } \\
\text { drate \% }\end{array}$ & $\underset{(\mathrm{mg} / \mathrm{kg})}{\mathrm{K}}$ & $\begin{array}{c}\mathrm{Mg} \\
(\mathrm{mg} / \mathrm{kg})\end{array}$ & $\begin{array}{c}\mathrm{Ca} \\
(\mathrm{mg} / \mathrm{kg})\end{array}$ & $\begin{array}{c}\mathrm{Fe} \\
(\mathrm{mg} / \mathrm{kg})\end{array}$ \\
\hline Dry gluten $\%$ & $\begin{array}{c}0.182 \\
(0.515)\end{array}$ & $\begin{array}{l}-0.428 \\
(0.111)\end{array}$ & $\begin{array}{l}-0.169 \\
(0.548)\end{array}$ & $\begin{array}{c}-0.161 \\
(0.568)\end{array}$ & $\begin{array}{c}0.133 \\
(0.635)\end{array}$ & $\begin{array}{c}0.179 \\
(0.524)\end{array}$ & $\begin{array}{c}-0.232 \\
(0.406)\end{array}$ & $\begin{array}{c}0.480 \\
(0.070)\end{array}$ & $\begin{array}{l}-0.114 \\
(0.686)\end{array}$ & $\begin{array}{c}0.157 \\
(0.576)\end{array}$ & $\begin{array}{c}-0.464 \\
(0.081)\end{array}$ & $\begin{array}{c}0.248 \\
(0.373)\end{array}$ \\
\hline Total Ash \% & & $\begin{array}{c}0.015 \\
(0.958)\end{array}$ & $\begin{array}{c}0.517 \\
(0.049)\end{array}$ & $\begin{array}{c}0.142 \\
(0.614)\end{array}$ & $\begin{array}{c}0.048 \\
(0.864)\end{array}$ & $\begin{array}{c}-0.381 \\
(0.161)\end{array}$ & $\begin{array}{c}-0.064 \\
(0.821)\end{array}$ & $\begin{array}{c}0.374 \\
(0.170)\end{array}$ & $\begin{array}{c}0.240 \\
(0.389)\end{array}$ & $\begin{array}{c}0.017 \\
(0.951)\end{array}$ & $\begin{array}{c}0.014 \\
(0.960)\end{array}$ & $\begin{array}{l}-0.114 \\
(0.685)\end{array}$ \\
\hline Wet gluten $\%$ & & & $\begin{array}{c}0.150 \\
(0.594)\end{array}$ & $\begin{array}{c}0.325 \\
(0.237)\end{array}$ & $\begin{array}{l}-0.233 \\
(0.403)\end{array}$ & $\begin{array}{c}0.134 \\
(0.634)\end{array}$ & $\begin{array}{c}0.433 \\
(0.107)\end{array}$ & $\begin{array}{l}-0.053 \\
(0.852)\end{array}$ & $\begin{array}{c}0.400 \\
(0.140)\end{array}$ & $\begin{array}{c}0.137 \\
(0.628)\end{array}$ & $\begin{array}{c}0.183 \\
(0.513)\end{array}$ & $\begin{array}{c}0.320 \\
(0.245)\end{array}$ \\
\hline Moisture \% & & & & $\begin{array}{c}0.161 \\
(0.566)\end{array}$ & $\begin{array}{l}-0.399 \\
(0.140)\end{array}$ & $\begin{array}{l}-0.759 \\
(0.001)\end{array}$ & $\begin{array}{l}-0.360 \\
(0.188)\end{array}$ & $\begin{array}{l}-0.181 \\
(0.518)\end{array}$ & $\begin{array}{c}0.012 \\
(0.966)\end{array}$ & $\begin{array}{l}-0.496 \\
(0.060)\end{array}$ & $\begin{array}{c}0.282 \\
(0.309)\end{array}$ & $\begin{array}{c}0.084 \\
(0.765)\end{array}$ \\
\hline Total fiber $\%$ & & & & & $\begin{array}{c}-0.249 \\
(0.370)\end{array}$ & $\begin{array}{l}-0.047 \\
(0.868)\end{array}$ & $\begin{array}{l}-0.043 \\
(0.878)\end{array}$ & $\begin{array}{c}0.207 \\
(0.459)\end{array}$ & $\begin{array}{l}-0.220 \\
(0.432)\end{array}$ & $\begin{array}{l}-0.378 \\
(0.164)\end{array}$ & $\begin{array}{l}-0.064 \\
(0.820)\end{array}$ & $\begin{array}{l}-0.279 \\
(0.314)\end{array}$ \\
\hline Total sugar \% & & & & & & $\begin{array}{l}-0.043 \\
(0.879)\end{array}$ & $\begin{array}{l}-0.006 \\
(0.983)\end{array}$ & $\begin{array}{c}0.305 \\
(0.269)\end{array}$ & $\begin{array}{c}0.067 \\
(0.814)\end{array}$ & $\begin{array}{c}0.310 \\
(0.260)\end{array}$ & $\begin{array}{l}-0.320 \\
(0.245)\end{array}$ & $\begin{array}{l}-0.317 \\
(0.250)\end{array}$ \\
\hline Fat $\%$ & & & & & & & $\begin{array}{c}0.502 \\
(0.057)\end{array}$ & $\begin{array}{l}-0.002 \\
(0.993)\end{array}$ & $\begin{array}{c}0.058 \\
(0.837)\end{array}$ & $\begin{array}{c}0.583 \\
(0.023)\end{array}$ & $\begin{array}{l}-0.167 \\
(0.551)\end{array}$ & $\begin{array}{c}0.353 \\
(0.197)\end{array}$ \\
\hline Protein \% & & & & & & & & $\begin{array}{c}0.183 \\
(0.515)\end{array}$ & $\begin{array}{c}0.348 \\
(0.203)\end{array}$ & $\begin{array}{c}0.329 \\
(0.231)\end{array}$ & $\begin{array}{l}-0.038 \\
(0.893)\end{array}$ & $\begin{array}{c}0.080 \\
(0.778)\end{array}$ \\
\hline $\begin{array}{c}\text { Carbohydrate } \\
\%\end{array}$ & & & & & & & & & $\begin{array}{l}-0.274 \\
(0.323)\end{array}$ & $\begin{array}{c}0.095 \\
(0.735)\end{array}$ & $\begin{array}{l}-0.328 \\
(0.232)\end{array}$ & $\begin{array}{l}-0.347 \\
(0.206)\end{array}$ \\
\hline $\mathrm{K}(\mathrm{mg} / \mathrm{kg})$ & & & & & & & & & & $\begin{array}{c}0.365 \\
(0.180)\end{array}$ & $\begin{array}{c}0.149 \\
(0.597)\end{array}$ & $\begin{array}{c}0.348 \\
(0.204)\end{array}$ \\
\hline $\mathrm{Mg}(\mathrm{mg} / \mathrm{kg})$ & & & & & & & & & & & $\begin{array}{c}0.175 \\
(0.532)\end{array}$ & $\begin{array}{c}0.112 \\
(0.691)\end{array}$ \\
\hline $\mathrm{Ca}(\mathrm{mg} / \mathrm{kg})$ & & & & & & & & & & & & $\begin{array}{l}-0.064 \\
(0.822)\end{array}$ \\
\hline $\mathrm{Fe}(\mathrm{mg} / \mathrm{kg})$ & & & & & & & & & & & & \\
\hline
\end{tabular}

reflects the protein content of flour. During an earlier study in Haryana, India comprised five different wheat varieties viz. $C$ $306, H-977, H W-2004, P B W-550 \& W H-542$, it was found that $C$ 306 contained maximum $(11.7 \%)$ dry gluten whereas minimum (7.7 \%) dry gluten was found in $H W-2004$ (Dangi \& Khatkar, 2017). In Madhya Pradesh, among four wheat cultivars $K W-11$, $P B W-343, C-306$ and Raj-3765 maximum wet gluten was exhibited in $C$-306 (36.54\%) whereas minimum wet gluten was found in $P B W-343$ (30.28 \%) (Kaushik et al., 2015). These results are in agreement with the findings of present study, which revealed that the farmers' wheat varieties had a wide range of wet and dry gluten content.

\subsection{Ash content}

The ash content has nutritional significance in wheat flour that represents the presence of mineral but excess ash also has bad impacts like undesirable darkening in dough and food products. In present study, ash percent was found significantly different in farmers' wheat varieties in the range of 1.45-2.07 per cent. In an earlier study conducted at Haryana and Punjab, which had included nine Indian wheat varieties shown a wide range of ash content from 1.14 to 2.15 per cent, $W H-1021$ variety had the lowest ash content, whereas $W H-157$ had the highest ash content (Panghal et al., 2017).

\subsection{Fat content:}

Fat is an important component of our diet, which is used as a concentrated source of energy, supplies nine calories per gram. Fat from wheat is associated with essential oils, choline, and vitamin E. In an earlier study conducted with twelve different released varieties viz. $W H-283, W H D-943, P B W-590, W H-1080$, WH-896, WH-711, PBW-550, DBW-17, WH-542, WH-1025, WH147 and $P B W-343$ from North India, the range of fat percentage was found as 2.62 - 3.48. Maximum fat was exhibited by $P B W$ 590 whereas minimum fat percentage was found in $\mathrm{WH}-1025$ (Punia et al., 2017). The results are in agreement with the findings 
of present study, which revealed that the farmers' wheat varieties contained fat in the range of 1.6 to 3.0 per cent.

\subsection{Sugar content}

Starch and sugars play important role for plant growth as well as for human consumption. Starch and sugars supply 3.75 calories per gram. Sugars and starch both are regarded as available because they are easily digested and converted to energy. Present study confirmed the wider range of total sugar content in farmers' wheat cultivar (1.3 to $4.8 \%$ ). Among earlier studied Indian wheat varieties viz. RSP-566, RSP-561, PBW-396, HD-2687, C-306, $P B W-175, R S P-81, P B W-550, D B W-17$ and $W H-542$, maximum total sugar content was reported in $P B W-175$ (5.8\%), whereas minimum value of total sugar content was found in $H D-2687$ (3.01\%) (Mallick et al., 2013).

\subsection{Fibre content}

Whole grain wheat flour contains both soluble and insoluble form of fibres, which are derived from wheat bran. Soluble and insoluble form of fibres play significant role in nutrition and digestion process. The fibre content of the wheat cultivars were found in the range of 1.3 to 2.9 per cent. The results of present study was found in agreement with a previous study where six different wheat varieties from four countries viz. Agil, Mulan, Zentos (Germany); Kovas DS (Lithuania); Mariboss (Denmark) and Rigi (Switzerland), maximum crude fiber content was found as 2.19 per cent in Mariboss (Denmark), whereas minimum crude fiber was found as 1.63 $\%$ in Rigi (Switzerland) (Alijosius et al., 2016).

\subsection{Mineral content}

More than ten percent ( $>0.8$ billion) people around the globe are malnourished whereas around twenty-five percent ( $>2$ billion) people are prone to single or multiple micronutrient deficiencies. Due to insufficient micronutrient content in food, around 50 percent of people of the world were at the risk of calcium (Ca) deficiency during 2011 (Kumsa et al., 2015). Iron deficiency is an essential concern in India where maximum number of women are affected with anaemia, followed by China, Pakistan, Nigeria and Indonesia (Rai et al., 2018). The farmers' varieties may provide a solution to solving the problems of acute nutrient deficiency.

In our study farmers' cultivar were found rich in iron content as compared to the checks and earlier reported wheat varieties (Eagling et al, 2014; Alijosius et al., 2016; Panghal et al., 2017; Punia et al., 2017). Results are in agreement with the earlier report, which suggested that the iron content in wheat varieties found in wide variation (Qureshi et al., 2002; Oury et al., 2006; Zhao et al., 2009) and study which revealed wide variation in the iron content in wheat cultivars as compared to modern wheat
(Cakmak et al., 2000; Monasterio \& Graham 2000). However, richness of iron was exhibited in most of the cultivars of our investigation, which may be due to soil and environmental factors and may be considered for further investigation. $\mathrm{Ca}$ and $\mathrm{Mg}$ contents in farmers' wheat varieties were found in agreement with earlier study where sixty-three wheat cultivars (56 historical, 7 modern) were analysed at Washington, USA and found Ca and $\mathrm{Mg}$ content in the range of 228- $568 \mathrm{mg} / \mathrm{kg}$ and $1145-1723$ $\mathrm{mg} / \mathrm{kg}$ respectively (Murphy et al., 2008). During their study, average $\mathrm{Ca}$ and $\mathrm{Mg}$ content was 417.9 and $1388 \mathrm{mg} / \mathrm{kg}$ respectively (Murphy et al., 2008), however in our study it was 447.00 and $1468.7 \mathrm{mg} / \mathrm{kg}$ respectively. The maximum K content was found in Bansi-local and Mohit-gold as $6000 \mathrm{mg} / \mathrm{kg}$ however in as similar study conducted in Sweden, where 321 organically cultivated winter and spring wheat cultivars were analysed and found maximum $\mathrm{K}$ content in primitive wheat cultivars as 4670 $\mathrm{mg} / \mathrm{kg}$ (Hussain et al., 2010). In present study only fat percent showed moderate positive correlation with $\mathrm{Mg}$ content and negative relationship with moisture percent however in a similar study wheat protein was negatively correlated with carbohydrate $(r=-0.93)$ (Khan et al., 1987).

The farmers' wheat cultivars with potential nutritional values may be identified disseminated and considered for nutritional oriented breeding program to develop new varieties and can also be incorporated in the nutrition supplement programs of the government to ensure nutrient security among the vulnerable population of women and children across the country.

\section{Acknowledgement}

Authors are thankful to the Centre for Analysis and Learning in Livestock and Food (CALF), National Dairy Development Board (NDDB), Anand, Gujarat and Navsari Agricultural University (NAU), Navsari, Gujarat for their support in biochemical analysis. We also acknowledge all the innovators and Mr. Surendra Kumar, progressive farmer, Uttar Pradesh for their wheat varieties. Gratitude to the Director, National Innovation Foundation- India for constant support and motivation to carry out the research and providing the infrastructure.

\section{Conflict of interest}

All the authors declare that there is no conflict of interest.

\section{References}

AACC International (2000) Approved methods of the American association of cereal chemists $10^{\text {th }}$ ed., American Association of Cereal Chemists, St. Paul, Minnesota, USA. 
Ahmed MSH, Kanzal MO, Fadhl GA (2016) Study the storage temperature \& periods on rheological properties of wheat flour. American Journal of Food Science and Technology 4: 135-140.

Alijosius S, Svirmickas GJ, Bliznikas S, Gruzauskas R, Sasyte V, Raceviciute-Stupeliene A, Kliseviciute V, Dauksiene A (2016) Grain chemical composition of different varieties of winter cereals. Zemdirbyste 103: 273-280.

Anonymous (2018) World Agricultural Production, United States Department of Agriculture USDA. Foreign Agricultural Service, Circular $\quad$ Series, WAP. https://apps.fas.usda.gov/psdonline/circulars/production.pdf, accessed on 05 June 2018.

AOAC (1990) Official methods of analysis (Method 945.16) (15 $5^{\text {th }}$ Edition), Association of Official Analytical Chemists. Washington, DC.

AOAC (2000) Official methods of analysis of the AOAC $\left(18^{\text {th }}\right.$ Edition), Association of Official analytical Chemists, Washington DC.

Belitz HD, Grosch W, Schieberle P (2009) Cereals and cereal products. In: Belitz HD, Grosch W, Schieberle P (Eds.), Food Chemistry, Springer, Berlin.

Cakmak I, Ozkan H, Braun HJ, Welch RM, Romheld V (2000) Zinc and iron concentrations in seeds of wild, primitive, and modern wheats. Food and Nutrition Bulletin 21: 401-403.

Choi I, Kang C, Lee C, Kim S (2016) Classification of 31 Korean Wheat (Triticum aestivum L.) cultivars based on the chemical compositions. Preventive Nutrition and Food Science 21: 393-397.

Cooper R (2005) Re-discovering ancient wheat varieties as functional foods. Journal of Traditional and Complementary Medicine 5: 138-143.

Dangi P, Khatkar BS (2017) Physicochemical and Gluten Quality Characteristics of Commercial Wheat Varieties. International Journal of Innovative Research in Science, Engineering and Technology 6: 13448-13454.

Dubois M, Gilles K, Hamilton JK, Rebers PA, Smith F (1951) Colorimetric method for determination of sugar. Nature 168:167-167.

Eagling T, Wawer AA, Shewry PR, Zhao FJ, Fairweather-Tait SJ (2014) Iron bioavailability in two commercial cultivars of wheat: comparison between whole grain and white flour and the effects of Nicotianamine and 2'-deoxymugineic acid on iron uptake into caco-2 cells. Journal of Agricultural and Food Chemistry 62: 10320-10325.

Fernandes S (2017) Farming took root in India only 10,000 years ago, study finds, Hindustan Times, India. Available on https://www.hindustantimes.com/mumbai-news/farming-tookroot-in-india-only-10-000-years-ago-study-finds/storyznhMgOYjQOWWtgX49PkUsJ.html, accessed on 05 June 2018.

Garvin DF, Welch RM, Finley JW (2006) Historical shifts in the seed mineral micronutrient concentration of US hard red winter wheat germplasm. Journal of the Science of Food and Agriculture 86: $2213-2220$.

Hartree EF (1972) Determination of protein-Modification of Lowry method that gives a linear photometric response. Analytical Biochemistry 48: 422-427.

Hussain A, Larsson H, Kuktaite R, Johansson E (2010) Mineral composition of organically grown wheat genotypes: contribution to daily minerals intake. International Journal of Environmental Research and Public Health 7: 3442-3456.

ISO 2170-1980 (1980) Methods for sampling cereals and pulses (as milled products), ISO, Switzerland.

Kaushik R, Kumar N, Sihag MK, Ray A (2015) Isolation, characterization of wheat gluten and its regeneration properties. Journal of Food Science and Technology 52: 5930-5937.

Key TJ, Allen NE, Spencer EA, Travis RC (2002) The effect of diet on risk of cancer. Lancet 360: 861-868.

Khan MA, Rana IA, Ullah I (1987) Nutritional evaluation of some commercial wheat varieties grown in Pakistan. Plant Foods for Human Nutrition 37: 253-260.

Koehler P, Wieser H (2013) Chemistry of Cereal Grains. In: Gobbetti, Marco, Ganzle, Michael (Eds.) Handbook on Sourdough Biotechnology, Springer, Boston, MA.

Kumssa DB, Joy EJM, Ander EL, Watts MJ, Young SD, Walker S, Broadley MR (2015) Dietary calcium and zinc deficiency risks are decreasing but remain prevalent. Scientific Reports 5: 1-11.

Lowry OH, Rosebrough NJ, Farr AL, Randall RJ (1951) Protein measurement with the Folin phenol reagent. Journal of Biological Chemistry 193: 265-275.

Lushington K (2012) The registration of plant varieties by farmers in India: A status report. Review of Agrarian Studies 2: 112-128.

Mallick SA, Azaz K, Gupta M, Sharma V, Sinha BK (2013) Characterization of grain nutritional quality in wheat. International Journal of Plant Physiology 18: 183-186.

Monasterio I, Graham RD (2000) Breeding for trace minerals in wheat. Food and Nutrition Bulletin 21: 392-396.

Murphy KM, Reeves PG, Jones SS (2008) Relationship between yield and mineral nutrient concentrations in historical and modern spring wheat cultivars. Euphytica 163: 381-390. 
Musaiger A, Al-Hazzaa HM (2012) Prevalence and risk factors associated with nutrition-related non-communicable diseases in the Eastern Mediterranean region. International Journal of General Medicine 5: 199-217.

Nagarajan S, Singh B (1997) Wheat: India and international collaboration. In: Braun HJ, Altay F, Kronstad WE, Beniwal SOS, McNab A (Ed.), Wheat: Prospects for Global Improvement, Kluwer Academic Publisher, Netherlands.

Nagarajan S (2005) Can India produce enough wheat even by 2020? Current Science 89: 1467-1471.

Nielsen SS (1994) Introduction to the chemical analysis of foods. Jones and Bartlett, Boston, 117.

Oury FX, Leenhardt F, Remesy C, Chanliaud E, Duperrier B, Balfourier F, Charmet G (2006) Genetic variability and stability of grain magnesium, zinc and iron concentrations in bread wheat. European Journal of Agronomy 25: 177-185.

Panghal A, Chhikara N, Khatkar BS (2017) Characterisation of Indian wheat varieties for chapatti (flat bread) quality. Journal of the Saudi Society of Agricultural Sciences. Available on https://www.sciencedirect.com/science/article/pii/S1658077X173 00334, accessed on 18 June 2018.

Protection of Plant Varieties and Farmers' Rights (PPV \& FR) Authority (2018) List of registered varieties certificate issued. Available on http://plantauthority.gov.in/List_of_Certificates.htm, accessed on 18 June 2018.

Punia S, Sandhua KS, Sirohaa AK (2017) Difference in protein content of wheat (Triticum aestivum L.): Effect on functional, pasting, colour and antioxidant properties. Journal of the Saudi Society of Agricultural Sciences. Available on https://www.sciencedirect.com/science/article/pii/S1658077X173 02588, accessed on 18 June 2018.

Qureshi IM, Khattak TN, Akhtar J (2002) Determination of iron in different types of wheat flours. International Journal of Agriculture and Biology 4: 297-299.
Rai RK, Fawzi WW, Barik A, Chowdhury A (2018) The burden of iron-deficiency anaemia among women in India: how have iron and folic acid interventions fared? WHO South-East Asia Journal of Public Health 7: 18-23.

Reynolds MP, Rajaram S, Sayre KD (1999) Physiological and genetic changes of irrigated wheat in the post-green revolution period and approaches for meeting projected global demand. Crop Science 39: 611-1621.

Safdar MN, Naseem K, Siddiqui N, Amjad M, Hameed T, Khalil S (2009) Quality evaluation of different wheat varieties for the production of unleavened flat bread (Chapatti). Pakistan Journal of Nutrition 8: 1773-1778.

Souci SW, Fachmann W, Kraut H (2008) Food composition and nutrition tables. Medpharm Scientific Publishers, Stuttgart, Germany.

Stein B (1998) A History of India. Blackwell Publishing, Oxford, US.

Stone B, Morell MK (2009) Carbohydrates. In: Khan K, Shewry PR (Eds). Wheat: Chemistry and Technology, American Association of Cereal Chemists, Saint Paul, Minnesota, USA.

Triboi E, Martre P, Triboi-Blondel AM (2003) Environmentally induced changes of protein composition for developing grains of wheat are related to changes in total protein content. Journal of Experimental Botany 54: 1731-1742.

Verma DK, Srivastav PP (2017) Proximate Composition, Mineral Content and Fatty Acids Analyses of Aromatic and Non-Aromatic Indian Rice. Rice Science, 24: 21-31.

Yemm EW, Wilus AJ (1954) The estimation of carbohydrates in plant extracts by anthrone. Biochemical Journal 57: 508-514.

Yu S, Tian L (2018) Breeding major cereal grains through the lens of nutrition sensitivity. Molecular Plant 11: 23-30.

Zhao FJ, Su YH, Dunham SJ, Rakszegi M, Bedo Z, McGratha SP, Shewry PR (2009) Variation in mineral micronutrient concentrations in grain of wheat lines of diverse origin. Journal of Cereal Science 49: 290-295. 